\title{
Pigment adaptations in surface phytoplankton along the eastern boundary of the Atlantic Ocean
}

\author{
R. G. Barlow ${ }^{1, *}$, J. Aiken ${ }^{2}$, G. F. Moore ${ }^{2}$, P. M. Holligan ${ }^{3}$, S. Lavender ${ }^{4}$ \\ ${ }^{1}$ Marine \& Coastal Management, Private Bag X2, Rogge Bay 8012, Cape Town, South Africa \\ ${ }^{2}$ Plymouth Marine Laboratory, Prospect Place, West Hoe, Plymouth PL1 3DH, UK \\ ${ }^{3}$ Southampton Oceanography Centre, Empress Dock, Southampton SO14 3ZH, UK \\ ${ }^{4}$ Institute of Marine Studies, University of Plymouth, Drake Circus, Plymouth PL4 8AA, UK
}

\begin{abstract}
Pigment and ocean colour data were used to characterise the phytoplankton at the surface along an eastern boundary transect of the Atlantic Ocean in May and June 1998. Five major regions were delineated, including the Benguela and Canary upwelling systems off SW and NW Africa, the temperate NE Atlantic, the northern oligotrophic gyre and a southern oligotrophic zone. Diagnostic indices were derived to assess the chemotaxonomic composition of the phytoplankton community, while photo-pigment indices were derived to investigate pigment adaptations across the regions. A large range in chlorophyll a concentrations was observed along the transect, varying from 0.03 to $30.6 \mathrm{mg} \mathrm{m}^{-3}$. The levels were high in the high productivity regions, with mean concentrations being 3-fold greater in the Benguela region compared to the Canary and temperate NE Atlantic. Chlorophyll a levels were low in the oligotrophic regions, but concentrations in the southern oligotrophic region were double those in the northern. Diagnostic indices revealed that microplankton dominated the community in the Benguela region, nanoplankton dominated the temperate NE Atlantic and a mixed community of micro- and nanoplankton were present in the Canary region. Picoplankton comprised the majority of the communities in the 2 oligotrophic regions. Photo-pigment indices indicated that variation in the chlorophyll a proportion of total pigments was small, averaging $45 \%$ across the transect, but the accessory pigment pool varied considerably. Chlorophyll $c$ and photosynthetic carotenoids were prominent in the high productivity regions, resulting in photosynthetic pigments (chlorophylls plus carotenoids) accounting for 87 to $93 \%$ of total pigments. In contrast, the level of photoprotective carotenoids was high in oligotrophic regions, resulting in a photosynthetic pigment content of only $68 \%$.
\end{abstract}

KEY WORDS: Pigment indices · Ocean colour · Atlantic Ocean · Eastern transect

\section{INTRODUCTION}

The oceans play a significant role in influencing global climate through such processes as heat transport and gas exchange with the atmosphere, while the cycling of carbon, in particular, is modulated by the phytoplankton via the mechanisms of photosynthesis and respiration (Aiken et al. 1992). A range of ecosystems of varying trophic status characterises the oceans, and one of the current objectives of marine research is to quantify the variation in phytoplankton biomass and production on basin-wide and global scales (Maranon et al. 2000). Longhurst et al. (1995) evaluated the large scale patterns in productivity from remotely sensed ocean colour data and promoted the concept of biogeochemical provinces. To further the understanding of basin-scale variability, the Atlantic Meridional Transect (AMT) programme was initiated to investigate the physical and biological processes in the Atlantic Ocean (Aiken et al. 2000). One of the goals of the AMT programme is to improve the knowledge of marine biogeochemical processes, ecosystem dynamics and food webs through comparison of contrasting ecosystems. 
AMT cruises are usually conducted between the United Kingdom (UK) and the Falklands Islands (FI), but one other transect was run between South Africa (SA) and the UK. Previous investigations on the UK-FI transect showed that phytoplankton biomass was elevated in the temperate NE Atlantic, in the NW African (Canary) upwelling region, and in the Brazil-Falklands Current Confluence Zone (BFCCZ), compared to the low biomass in oligotrophic regions (Maranon \& Holligan 1999, Maranon et al. 2000). Pigment chemotaxonomic studies revealed that eukaryotic diatoms and nanoflagellates were more abundant in surface waters in the high productivity regions, while cyanobacteria and prochlorophytes dominated the oligotrophic areas (Gibb et al. 2000). Barlow et al. (2002) compared the vertical distribution pattern of pigments between the UK-FI and the UK-SA transects and found that the chlorophyll a concentrations in the Benguela upwelling region were twice those in the BFCCZ, with diatoms dominating in the Benguela and nanoflagellates in the BFCCZ. Seasonal differences were observed in the Canary upwelling zone, where chlorophyll a levels were twice as high in the upper mixed layer in the spring relative to autumn, and the community was composed mainly of diatoms and nanoflagellates (Barlow et al. 2002).

The major role of chlorophyll a in phytoplankton is to absorb light for photosynthesis, but there are additional accessory pigments, the chlorophylls $b$ and $c$ and various carotenoids, which have a significant function in extending the light-harvesting spectrum in the phytoplankton, thus ensuring optimal absorption efficiencies (Kirk 1994). Other carotenoids, however, serve to protect microalgal cells against the effects of high irradiances that may damage the photosynthetic apparatus, and these pigments may be termed photoprotective carotenoids (Kirk 1994). The ratio of individual accessory pigments to chlorophyll a can vary with changes in community composition and physiological state, but the relationship between total accessory pigments and chlorophyll $a$ is remarkably robust (Trees et al. 2000). Trees et al. (2000) demonstrated that the ratio of accessory pigments to chlorophyll $a$ is constant at 0.934 for a global dataset of 5600 samples covering all trophic levels, with $95 \%$ of the variance explained.

Photosynthetic carotenoids are reported to be more prominent in high productivity ecosystems (Barlow et al. 2002), accounting for $80 \%$ of total carotenoids (Gibb et al. 2000). On the other hand, photoprotective carotenoids are dominant at the surface in low chlorophyll waters and can be $>70 \%$ of the carotenoid pool (Gibb et al. 2000). These differences are associated with changes in phytoplankton community structure (Gibb et al. 2000, Trees et al. 2000, Barlow et al. 2002), but can also be due to physiological responses to changing light and environmental conditions (Trees et al. 2000). In this investigation, the objective was to examine the variability within the total pigment pool, to gain an insight into pigment adaptations in surface phytoplankton between contrasting regions along the eastern boundary of the Atlantic Ocean. Five major regions were identified for comparison over $84^{\circ}$ of latitude between South Africa and the UK.

\section{MATERIALS AND METHODS}

The AMT-6 cruise was conducted between South Africa and the UK during May and June 1998. Underway near-surface temperature and salinity were recorded with an SBE thermosalinograph, and by the CTD on station. High resolution SeaWiFS (Sea-viewing Wide Field-of-view Sensor) ocean colour images were sent to the ship from NASA Goddard Space Flight Centre each day and these were used to adjust the daily sampling strategy. Post cruise processing and compositing of SeaWiFS data was conducted at the Plymouth Marine Laboratory to produce regional images of pigment distribution using the NASA OC2V2 chlorophyll a algorithm (O'Reilly et al. 1998).

Seawater was collected in underway mode every $2 \mathrm{~h}$ from the non-contaminated seawater supply (intake at $4 \mathrm{~m}$ ), and from the daily CTD deployment on station, filtered through $25 \mathrm{~mm}$ GF/F filters to harvest the phytoplankton, and filters were stored frozen in a $-60^{\circ} \mathrm{C}$ freezer or in liquid nitrogen. Pigments were extracted in acetone with the aid of ultrasonication and clarified by centrifugation. On board analysis of pigments followed the reverse phase HPLC procedure outlined by Barlow et al. (1997) using a $3 \mu \mathrm{m}$ Hypersil MOS2 C8 column $(100 \times 4.6 \mathrm{~mm})$, a Shimadzu HPLC system, a Thermo Separations AS3000 autosampler, a Thermo Separations UV6000 diode array absorbance detector and PC1000 chromatography software. Pigments were detected at 440 and $665 \mathrm{~nm}$, and identified by retention time and on-line diode array spectra. Chlorophyll a standard was obtained from SigmaAldrich, and divinyl chlorophylls $a$ and $b$ from R. Bidigare and M. Ondrusek, University of Hawaii. Other pigment standards were purchased from the DHI Institute for Water and Environment, Denmark. The method separates divinyl and monovinyl chlorophyll $a$, zeaxanthin and lutein, and achieves partial separation of divinyl and monovinyl chlorophyll $b$. Limits of detection were of the order of $0.001 \mathrm{mg} \mathrm{m}^{-3}$.

Diagnostic pigment indices were derived to assess the composition of phytoplankton communities, following the method of Vidussi et al. (2001). Diagnostic pigments (DP) were defined as the sum of 7 selected biomarker pigments, as given in Table 1. Total chloro- 
Table 1. Symbols, names and formulae for chlorophylls, carotenoids, pigment sums and pigment indices

\begin{tabular}{|c|c|c|}
\hline Symbol & Pigment & Formula \\
\hline Chla & Chlorophyll a (plus allomers and epimers) & \\
\hline Chlb & Chlorophyll $b$ & \\
\hline $\mathrm{Chlc}_{1}$ & Chlorophyll $c_{1}$ & \\
\hline $\mathrm{Chlc}_{2}$ & Chlorophyll $c_{2}$ & \\
\hline $\mathrm{Chlc}_{3}$ & Chlorophyll $c_{3}$ & \\
\hline Chlidea & Chlorophyllide $a$ & \\
\hline DVChla & Divinyl chlorophyll a & \\
\hline All & Alloxanthin & \\
\hline But & 19'-Butanoyloxyfucoxanthin & \\
\hline Caro & Carotenes & $\beta, \beta$-Carotene $+\beta, \varepsilon$-Carotene \\
\hline Diad & Diadinoxanthin & \\
\hline Diato & Diatoxanthin & \\
\hline Fuc & Fucoxanthin & \\
\hline Lut & Lutein & \\
\hline Hex & 19'-Hexanoyloxyfucoxanthin & \\
\hline Per & Peridinin $1+1$ & \\
\hline Viol & Violaxanthin & \\
\hline Zea & Zeaxanthin & \\
\hline TChla & Total chlorophyll a & Chla + DVChla + Chlidea \\
\hline TChlc & Total chlorophyll $c$ & $\mathrm{Chlc}_{1}+\mathrm{Chlc}_{2}+\mathrm{Chlc}_{3}$ \\
\hline Chlbc & Sum of chlorophyll $b$ and $c$ & Chlb + TChlc \\
\hline $\mathrm{PPC}$ & Photoprotective carotenoids & $\mathrm{All}+\mathrm{Caro}+$ Diad + Diato + Lut + Viol + Zea \\
\hline PSC & Photosynthetic carotenoids & But + Fuc + Hex + Per \\
\hline TPig & Total pigments & TChla + Chlbc + PPC + PSC \\
\hline DP & Diagnostic pigments & $\mathrm{All}+\mathrm{But}+\mathrm{Chlb}+\mathrm{Fuc}+\mathrm{Hex}+\mathrm{Per}+\mathrm{Zea}$ \\
\hline DVChla/TChla & Divinyl chlorophyll $a$ to total chlorophyll $a$ & DVChla/TChla \\
\hline $\mathrm{TChla}_{\mathrm{TP}}$ & Total chlorophyll a to total pigments & TChla/TPig \\
\hline $\mathrm{Chlbc}_{\mathrm{TP}}$ & Sum of chlorophyll $b$ and $c$ to total pigments & Chlbc/TPig \\
\hline TChlC $_{\mathrm{TP}}$ & Total chlorophyll $c$ to total pigments & TChlc/TPig \\
\hline $\mathrm{PPC}_{\mathrm{TP}}$ & Photoprotective carotenoids to total pigments & PPC/TPig \\
\hline $\mathrm{PSC}_{\mathrm{TP}}$ & Photosynthetic carotenoids to total pigments & PSC/TPig \\
\hline Micro $_{\mathrm{DP}}$ & Microplankton proportion of DP & $($ Fuc + Per $) / D P$ \\
\hline $\mathrm{Nano}_{\mathrm{DP}}$ & Nanoplankton proportion of DP & $(\mathrm{All}+\mathrm{But}+\mathrm{Hex}) / \mathrm{DP}$ \\
\hline $\mathrm{PiCO}_{\mathrm{DP}}$ & Picoplankton proportion of DP & $(\mathrm{Chlb}+\mathrm{Zea}) / \mathrm{DP}$ \\
\hline
\end{tabular}

phyll a concentration (TChla) was estimated as the sum of monovinyl chlorophyll $a$, divinyl chlorophyll $a$, chlorophyllide $a$, and chlorophyll a allomers and epimers. A linear regression between DP and TChla showed a significant relationship $\left(\mathrm{r}^{2}=0.97, \mathrm{n}=284, \mathrm{p}<\right.$ 0.01), indicating that DP is also a valid estimate of phytoplankton biomass. Three major phytoplankton groups were characterised, namely microplankton, nanoplankton and picoplankton, following the criteria of Vidussi et al. (2001). The indices symbolising these groups were designated Micro $_{D P}, \mathrm{Nano}_{\mathrm{DP}}$ and $\mathrm{PiCO}_{\mathrm{DP}}$ respectively, and the proportion of each group contributing to the biomass was defined as given in Table 1. The microplankton consisted of diatoms (Fuc) and dinoflagellates (Per), the nanoplankton of goldenbrown flagellates (Hex, But) and cryptophytes (All), while the picoplankton comprised the cyanobacteria plus prochlorophytes (Zea) and green flagellates (Chlb).

The identified groups do not conform strictly to the actual size of the phytoplankton, based on size- fractionated sampling, but oligotrophic samples contain a high level of zeaxanthin, where cyanobacteria and prochlorophytes are <2 $\mu \mathrm{m}$ (Moore et al. 1995, Jeffrey \& Vesk 1997), with a smaller contribution from Chlb. Simon et al. (1994) demonstrated that a wide variety of picoflagellates isolated from the tropical NE Atlantic contain Chlb, and Jeffrey (1976) was the first to report the extensive occurrence of Chlb in oligotrophic Pacific waters. The grouping of cyanobacteria, prochlorophytes and green flagellates in the picoplankton group is therefore appropriate. Although the golden-brown flagellates (Hex, But) can comprise both pico- and nanoflagellates (Jeffrey \& Vesk 1997), nanoflagellates were more abundant along the transect. This observation was based on the considerably greater concentration of Hex compared to But, and that Hex-containing flagellates are mostly in the nanoplankton range of 2 to $20 \mu \mathrm{m}$ (Jeffrey \& Vesk 1997). Alloxanthin was generally detected in high productivity waters, and since cryptophytes are 6 to $20 \mu \mathrm{m}$ in size (Jeffrey \& Vesk 1997), it is relevant to 
include them in the nanoplankton group. Diatoms and dinoflagellates span a wide range in size from 5 to $200 \mu \mathrm{m}$ (Jeffrey \& Vesk 1997), and small cells can dominate in many regions of the world ocean. However, microscopic observations during the cruise revealed that although there were small diatoms and dinoflagellates present in seawater samples, large cells $>20 \mu \mathrm{m}$ occurred in greater abundance, especially in the Benguela and Canary upwelling ecosystems, and the temperate NE Atlantic. No extensive microscopic analysis of phytoplankton was undertaken within the cruise programme and only selected qualitative observations were done on board. Since large cells occurred in greater abundance than small cells, fucoxanthin and peridinin were allocated to the microplankton group.

Photo-pigment indices were derived to assess the changing contribution of chlorophylls and carotenoids to the total pigment pool. The chlorophylls were proportioned into TChla and the sum of chlorophyll $b$ plus chlorophyll $C^{\prime}$ s (Chlbc). The carotenoids were identified as the photosynthetic carotenoids (PSC) and the photoprotective carotenoids (PPC). The 4 photopigment indices were symbolised as TChla ${ }_{\mathrm{TP}}, \mathrm{Chlbc}_{\mathrm{TP}}$, $\mathrm{PSC}_{\mathrm{TP}}$ and $\mathrm{PPC}_{\mathrm{TP}}$, and defined as given in Table 1. The carotenes were included in the photoprotective pool, but while $\beta, \beta$-carotene is a non-photosynthetic pigment in eukaryotes (Porra et al. 1997), $\beta, \beta$-carotene and $\beta, \varepsilon$-carotene are considered to be photosynthetic carotenoids in cyanobacteria (Kana et al. 1988, Moore et al. 1995). Photoprotective and photosynthetic carotenes were not distinguished in this study and, therefore, the $\mathrm{PPC}_{\mathrm{TP}}$ index may be overestimated (and the $\mathrm{PSC}_{\mathrm{TP}}$ index underestimated) when cyanobacteria are abundant in oligotrophic waters. Zeaxanthin is, however, the dominant photoprotective pigment in cyanobacteria (Moore et al. 1995) and the contribution of carotenes to the PPC was estimated to be $11.2 \%$ in oligotrophic regions and $15.1 \%$ in meso- and eutrophic regions. The diagnostic indices reveal that picoplankton accounted for an overall mean of $55 \%$ of DP in oligotrophic waters and, therefore, the $\mathrm{PPC}_{\mathrm{TP}}$ index was overestimated by $6.2 \%$.

\section{RESULTS}

\section{Hydrography and satellite ocean colour}

The cruise track from South Africa to the United Kingdom is shown in Fig. 1. Temperature and salinity (Fig. 2) varied considerably along the transect, with cool $\left(13\right.$ to $\left.16^{\circ} \mathrm{C}\right)$, low salinity waters $(34.5$ to 35.1$)$ being monitored in the southern Benguela (34 to $\left.25^{\circ} \mathrm{S}\right)$. In the northern Benguela $\left(25\right.$ to $15.5^{\circ} \mathrm{S}$ ) and

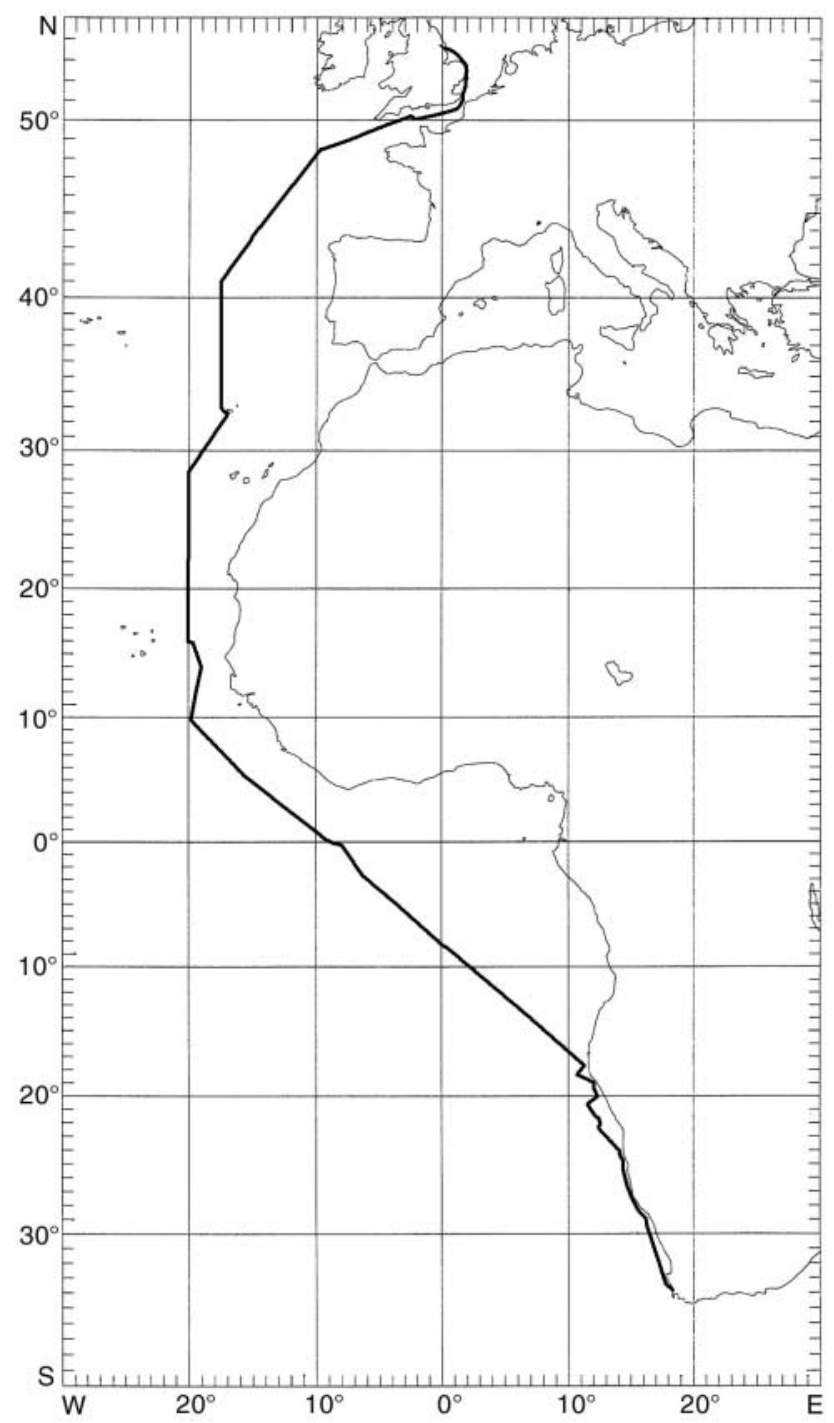

Fig. 1. Cruise track along the eastern boundary of the Atlantic Ocean in May-June 1998

through to $12^{\circ} \mathrm{S}$, the temperature and salinity increased concomitantly to ca. $26^{\circ} \mathrm{C}$ and 36.7 , respectively. In the equatorial zone $\left(12^{\circ} \mathrm{S}\right.$ to $\left.20^{\circ} \mathrm{N}\right)$, excessive precipitation led to a significant fall in surface salinity to 2 minima at $8^{\circ} \mathrm{S}(34.7)$ and at 2 to $7^{\circ} \mathrm{N}(34.4$, North Equatorial Counter Current), with a maximum on the equator (35.5) due to equatorial upwelling. Temperature increased steadily from $12^{\circ} \mathrm{S}$ latitude to reach a maximum of $29^{\circ} \mathrm{C}$ between 2 and $10^{\circ} \mathrm{N}$, except for a minimum $\left(25.6^{\circ} \mathrm{C}\right)$ corresponding to the equatorial upwelling. Northwards, temperature declined from $10^{\circ} \mathrm{N}$ latitude and salinity remained approximately constant to latitude $21^{\circ} \mathrm{N}$. At $21^{\circ} \mathrm{N}$, there was a marked increase in salinity and an increase in temperature, indicating the occurrence of a front at the inter- 


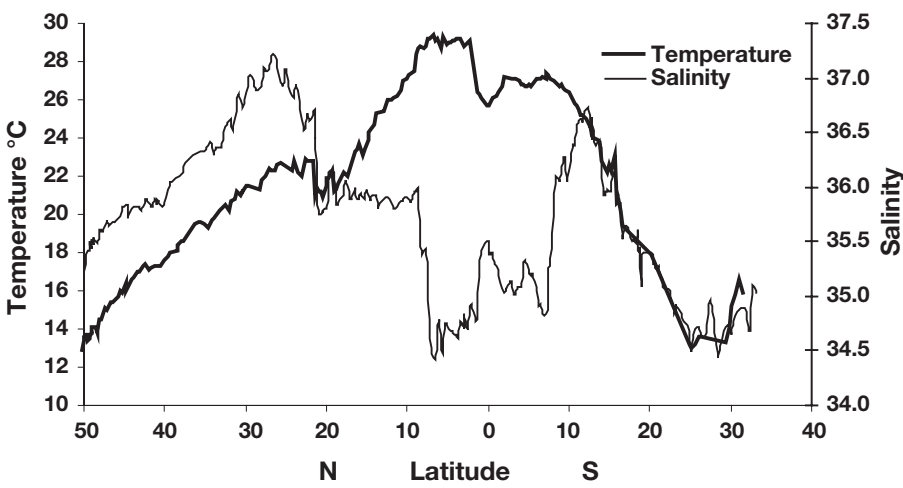

Fig. 2. Surface temperature and salinity along the eastern transect

face between upwelled and oligotrophic water masses. Thereafter $\left(25\right.$ to $\left.50^{\circ} \mathrm{N}\right)$, temperature and salinity declined concomitantly, consistent with a conservative evaporation-precipitation relationship typical of the sub-tropical and temperate zones.

Fig. 3 shows composite SeaWiFS images of chlorophyll a distribution for the NE Atlantic and the Benguela and Canary upwelling regions for May and June 1998. The end of the phytoplankton spring bloom in the temperate NE Atlantic in June 1998 is depicted in the chlorophyll a image in Fig. 3a. The image covers a large area and shows the extensive phytoplankton distribution from $44^{\circ} \mathrm{N}$ through to $51-52^{\circ} \mathrm{N}$, and the patchy nature of the distribution pattern. The chlorophyll a image for NW Africa indicated the effects of upwelling in this region during spring, with elevated pigment levels extending for at least $7^{\circ}$ of longitude $\left(16\right.$ to $\left.23^{\circ} \mathrm{W}\right)$, and the variations illustrate the patchy nature of the phytoplankton distribution (Fig. 3b). The sharp front at $21^{\circ} \mathrm{N}$ demarcated the boundary between the productive upwelling waters and the oligotrophic gyre in the tropical NE Atlantic. A wide band of high chlorophyll a was present along the SW African coast, extending for a considerable distance offshore (Fig. 3c), and the image reveals distinct, convoluted boundaries between eutrophic waters and the offshore oligotrophic water masses. The images highlight the contrast between the relatively high chlorophyll a concentrations (5.0 to $30.0 \mathrm{mg} \mathrm{m}^{-3}$ ) in upwelling and temperate regions, compared to the low levels in oligotrophic waters $\left(0.06\right.$ to $\left.0.2 \mathrm{mg} \mathrm{m}^{-3}\right)$.

Fig. 3. Chlorophyll a concentration for (a) the NE Atlantic, (b) the Canary upwelling system, and (c) the Benguela ecosystem, as observed by SeaWiFS in May-June 1998. Note that the scaling is logarithmic and the scales are different in (a), (b) and (c)
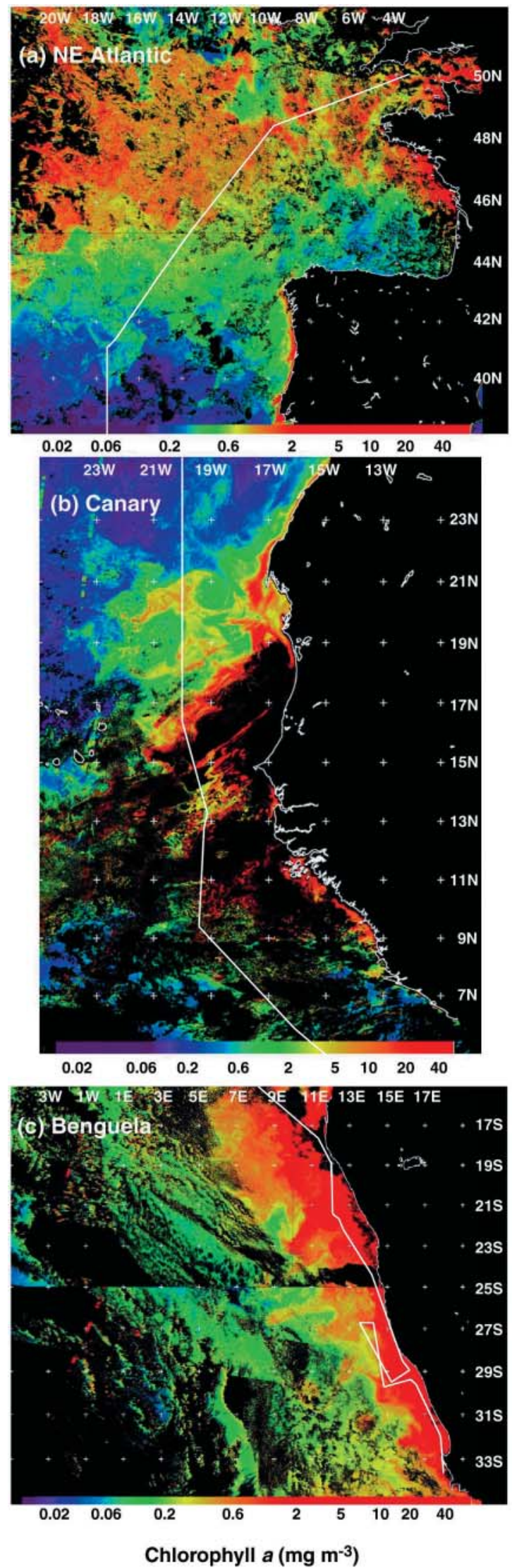


\section{Pigment indices}

Five major regions were identified across the transect, with the purpose of evaluating inter-regional differences. Boundaries for each region were assessed from the changes in TChla and photo-pigment indices (Figs. 4 \& 5). The Benguela upwelling region (34 to $15.5^{\circ} \mathrm{S}$ ) was designated as a high TChla region (>0.4 $\mathrm{mg} \mathrm{m}^{-3}$, Fig. 4a) where divinyl chlorophyll a (DVChla) levels were below the detection limit (Fig. 4b), while the southern oligotrophic region $\left(15.5^{\circ} \mathrm{S}\right.$ to $\left.15^{\circ} \mathrm{N}\right)$ was characterised by low TChla levels $\left(<0.4 \mathrm{mg} \mathrm{m}^{-3}\right.$, Fig. $\left.4 \mathrm{a}\right)$ and elevated $\mathrm{PPC}_{\mathrm{TP}}$ indices (Fig. 5b). The Canary upwelling region was bounded at $15^{\circ} \mathrm{N}$, where TChla and $\mathrm{PSC}_{\mathrm{TP}}$ increased, and at $21^{\circ} \mathrm{N}$, where TChla and $\mathrm{PSC}_{\mathrm{TP}}$ declined sharply across a front (Figs. 4a \& 5b). The northern oligotrophic region $\left(21\right.$ to $\left.40^{\circ} \mathrm{N}\right)$ contained low TChla levels $\left(<0.4 \mathrm{mg} \mathrm{m}^{-3}\right.$, Fig. 4a) and elevated $\mathrm{PPC}_{\mathrm{TP}}$ indices (Fig. 5b), and the temperate NE Atlantic region (40 to $50^{\circ} \mathrm{N}$ ) was characterised by elevated TChla concentrations (Fig. 4a) and PSC $\mathrm{TP}_{\mathrm{P}}$ indices (Fig. 5b).
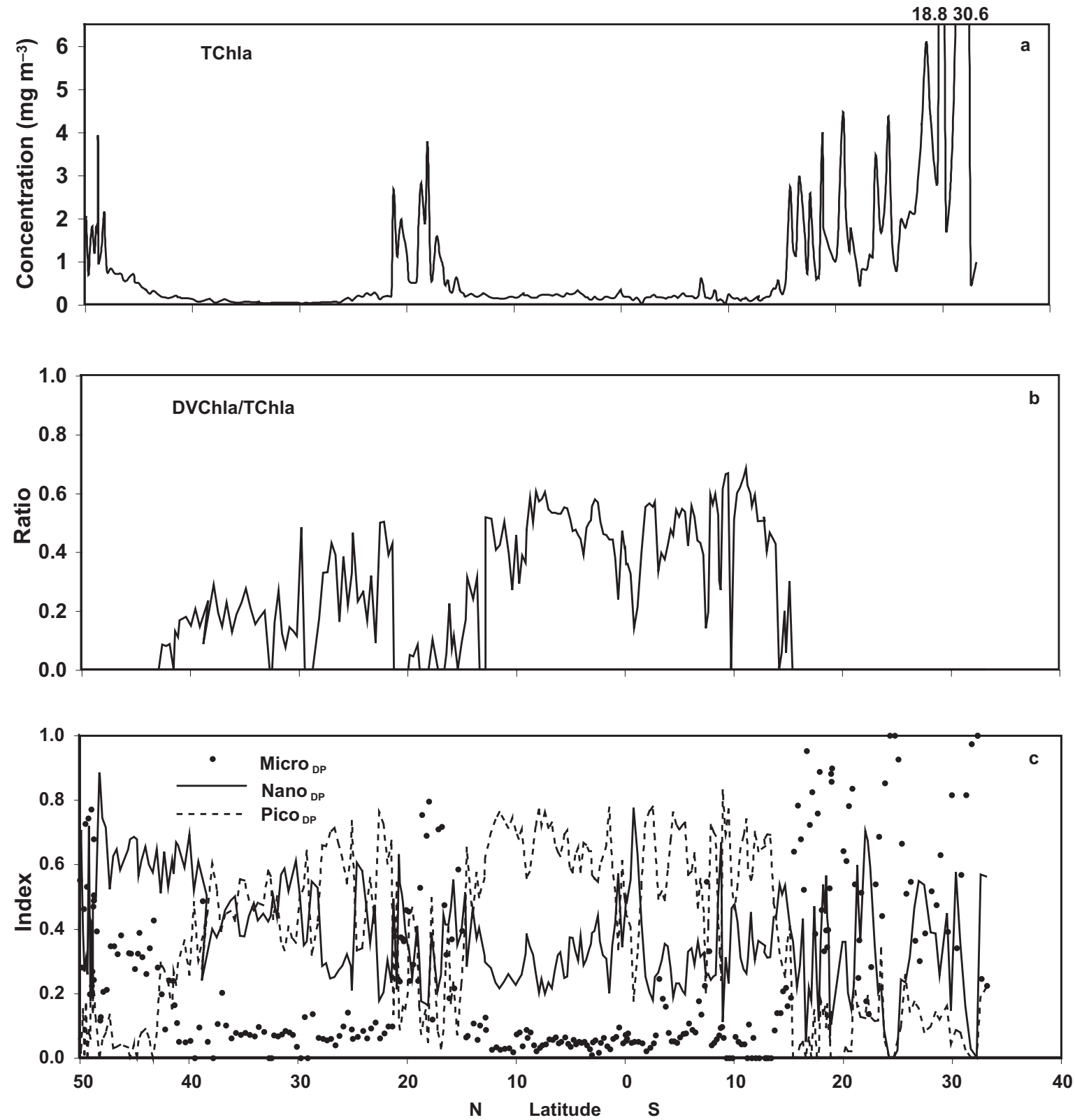

Fig. 4. (a) Surface TChla concentrations, (b) DVChla/TChla ratios, and (c) diagnostic indices, along the transect. Panel (a) has an expanded scale along the $y$-axis and the numbers indicate concentrations at the off-scale peak heights. See Table 1 for abbreviations 

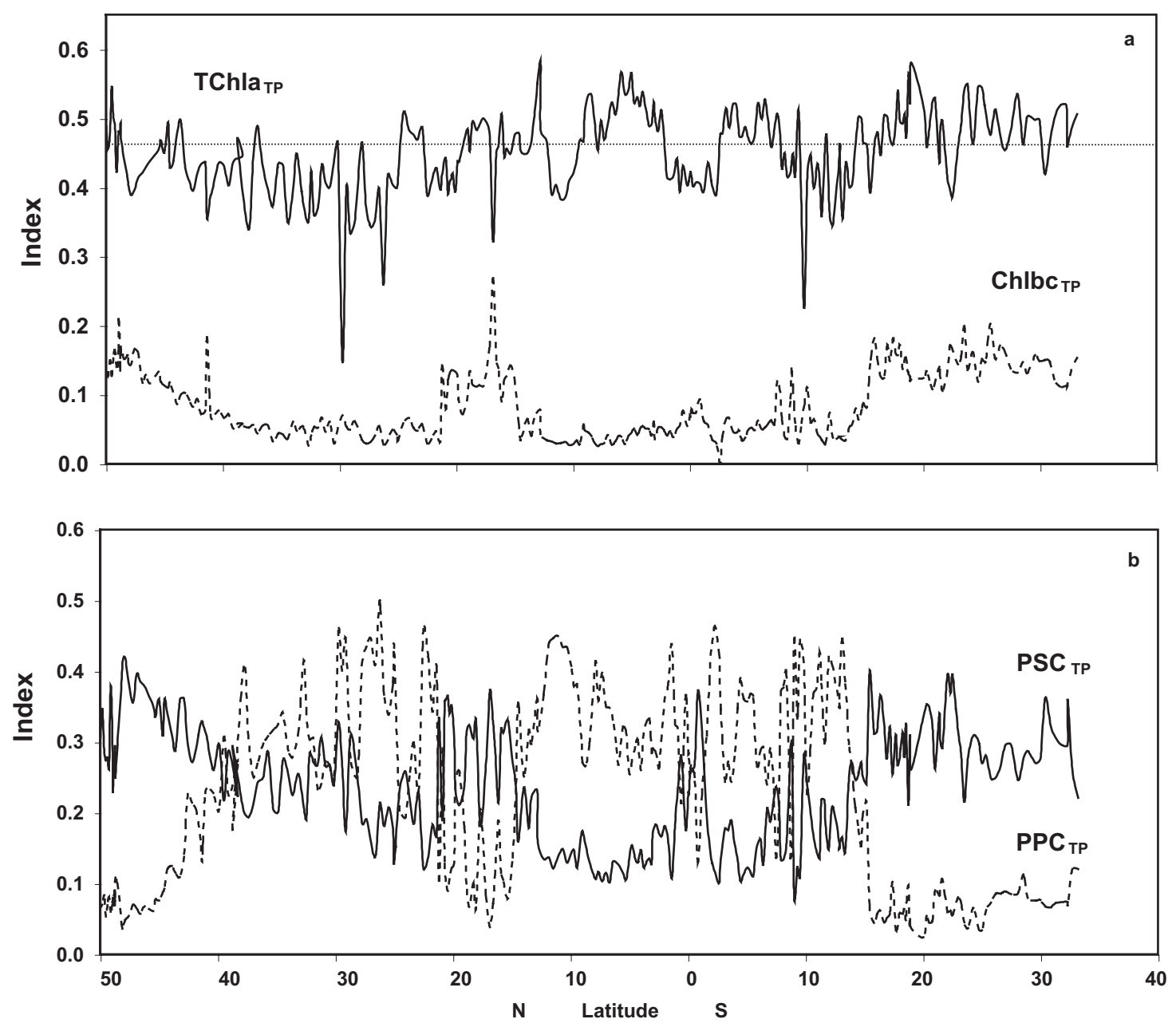

Fig. 5. Variations in photo-pigment indices along the transect in May-June 1998. (a) $\mathrm{TChla}_{\mathrm{TP}}$ and $\mathrm{ChlbC}_{\mathrm{TP}}$ (b) $\mathrm{PSC}_{\mathrm{TP}}$ and $\mathrm{PPC}_{\mathrm{TP}}$. Horizontal dotted line in (a) is the mean of all TChla values. See Table 1 for abbreviations

Fig. 4a shows the changing pattern of TChla along the transect in May and June 1998. Elevated TChla levels were observed in the 3 high productivity regions, but the considerable variation in concentration demonstrated the highly patchy nature of the phytoplankton distribution. Two very high chlorophyll patches were sampled in the southern Benguela with concentrations of 18.8 and $30.6 \mathrm{mg} \mathrm{m}^{-3}$ (Fig. 4a). Very low levels were recorded in the NE Atlantic gyre (21 to $40^{\circ} \mathrm{N}_{i}<0.2 \mathrm{mg} \mathrm{m}^{-3}$ ), while TChla in the southern oligotrophic zone $\left(15^{\circ} \mathrm{S}\right.$ to $\left.15^{\circ} \mathrm{N}\right)$ was greater at 0.2 to $0.4 \mathrm{mg} \mathrm{m}^{-3}$. An assessment of the divinyl chlorophyll $a$ (DVChla) contribution to TChla is illustrated in Fig. 4b. DVChla was below the detection limit throughout the Benguela ecosystem and in the temperate NE Atlantic from 43 to $50^{\circ} \mathrm{S}$. Low DVChla/TChla ratios were observed at 15 to $21^{\circ} \mathrm{N}$, while the highest ratios were determined for the oligotrophic waters between $15.5^{\circ} \mathrm{S}$ and $15^{\circ} \mathrm{N}$ (up to 0.68 ). Ratios were lower in the NE
Atlantic gyre and declined towards the northern latitudes (Fig. 4b).

The variation in diagnostic indices revealed that microplankton $\left(\right.$ Micro $_{\mathrm{DP}}$ ) dominated the phytoplankton in the Benguela ecosystem (Fig. 4c), where elevated fucoxanthin concentrations indicated that diatoms were generally the most important class. The 2 high chlorophyll patches in the southern Benguela at $29^{\circ} \mathrm{S}$ and $31^{\circ} \mathrm{S}$ were due to the presence of dinoflagellates, as indicated by high concentrations of peridinin. Microplankton were also significant off NW Africa (15 to $21^{\circ} \mathrm{N}$ ) and in the temperate NE Atlantic (40 to $50^{\circ} \mathrm{N}$ ), generally due to diatoms since peridinin concentrations were low. Nanoplankton $\left(\mathrm{Nano}_{\mathrm{DP}}\right)$ were ubiquitous throughout the transect, being significant in all regions, and there was an increasing trend in the Nano $_{\text {DP }}$ index from the southern to the northern latitudes, with nanoplankton dominating the community in the temperate NE Atlantic $\left(40\right.$ to $\left.48^{\circ} \mathrm{N}\right)$ (Fig. 4c). The 
$\mathrm{PiCO}_{\mathrm{DP}}$ indices were low in the Benguela and temperate NE Atlantic, variable off NW Africa, but high in oligotrophic waters at latitudes $15.5^{\circ} \mathrm{S}$ to $15^{\circ} \mathrm{N}$ and 21 to $40^{\circ} \mathrm{N}$ (Fig. 4c). The picoplankton in the Benguela and the temperate NE Atlantic most probably consisted of the cyanobacterium Synechococcus sp., as only zeaxanthin was detected. The picoplankton most likely comprised both Synechococcus and Prochlorococcus between $15.5^{\circ} \mathrm{S}$ and $40^{\circ} \mathrm{N}$, where both zeaxanthin and DVChla were detected.

There was a concomitant variability in photopigment indices with the change in community structure along the transect. The TChla $\mathrm{TP}_{\mathrm{P}}$ index (Fig. 5a) varied between 0.35 and 0.55 , but no particular trend was associated with any region. $\mathrm{Chlbc}_{\mathrm{TP}}$ indices were generally in the range 0.05 to 0.2 , but were greater in the high productivity regions relative to the oligotrophic regions (Fig. 5a). Chlorophyll $b$ levels were low throughout the transect and the variability in $\mathrm{Chlbc}_{\mathrm{TP}}$ indices was due to changes in chlorophyll $c$ concentrations. The $\mathrm{PSC}_{\mathrm{TP}}$ and $\mathrm{PPC}_{\mathrm{TP}}$ indices showed distinctive regional differences. $\mathrm{PSC}_{\mathrm{TP}}$ was elevated in the 3 high productivity regions, while $\mathrm{PPC}_{\mathrm{TP}}$ indices were high in oligotrophic waters, except at the equator, where $\mathrm{PPC}_{\mathrm{TP}}$ indices decreased as PSP $\mathrm{TP}$ increased (Fig. 5b).

A comparison of regional differences across the transect was facilitated by averaging the data in each region (Fig. 6). The mean TChla for the Benguela region $\left(3.59 \mathrm{mg} \mathrm{m}^{-3}\right.$ ) was 3 times greater than the mean concentrations for the Canary $\left(1.32 \mathrm{mg} \mathrm{m}^{-3}\right)$ and temperate NE Atlantic (0.97 $\left.\mathrm{mg} \mathrm{m}^{-3}\right)$ regions (Fig. 6a). Mean TChla was twice as high for the southern oligotrophic region $\left(0.19 \mathrm{mg} \mathrm{m}^{-3}\right.$ ) compared to the northern oligotrophic region $\left(0.08 \mathrm{mg} \mathrm{m}^{-3}\right)$. These comparisons suggest that the eastern boundary regions of the $\mathrm{S}$ Atlantic are more productive than the N Atlantic in
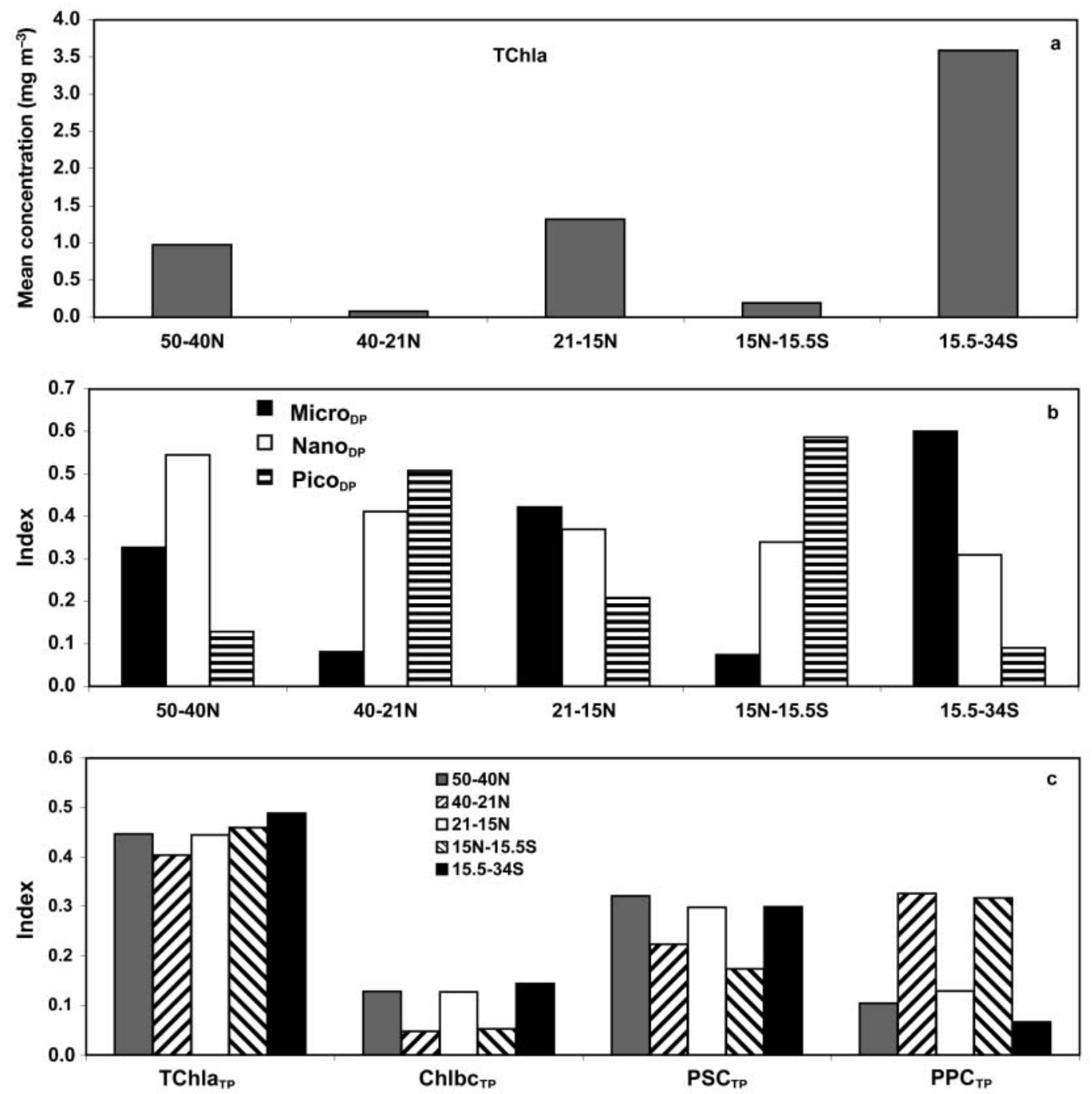

Fig. 6. (a) Mean TChla concentrations, (b) diagnostic indices, and (c) photo-pigment indices for 5 regions along the transect. See Table 1 for abbreviations 
May and June, but a comprehensive analysis of mesoscale satellite data would be required to prove this hypothesis.

The mean diagnostic indices indicated the contrasting dominance of microplankton $\left(\right.$ Micro $\left._{\mathrm{DP}}\right)$ in the Benguela ecosystem and picoplankton $\left(\mathrm{PiCO}_{\mathrm{DP}}\right)$ in the southern oligotrophic region (Fig. 6b). The proportions of micro- and nanoplankton (Micro $_{\mathrm{DP}}, \mathrm{Nano}_{\mathrm{DP}}$ ) were similar off NW Africa, although the picoplankton proportion was also significant. Picoplankton ( $\left.\mathrm{PiCO}_{\mathrm{DP}}\right)$ were the most abundant group between 21 and $40^{\circ} \mathrm{N}$, together with the nanoplankton, while $\mathrm{Nano}_{\mathrm{DP}}$ indices were the highest for the whole transect in the temperate NE Atlantic (Fig. 6b). The mean photo-pigment $\mathrm{TChla}_{\mathrm{TP}}$ index showed only small differences between regions, with the index tending to be slightly greater in the 2 southern regions (Fig. 6c). A statistical test (t-test) comparing all 5 regions gave a transect average, and a $95 \%$ confidence interval, of $0.449 \pm 0.027$ for TChla $\mathrm{TP}_{\mathrm{TP}}$. In contrast, the other photo-pigment indices varied considerably. Chlbc $\mathrm{TP}_{\mathrm{TP}}$ and $\mathrm{PSC}_{\mathrm{TP}}$ were elevated in the 3 high productivity regions, whereas $\mathrm{PPC}_{\mathrm{TP}}$ was high in the oligotrophic regions compared to the productive regions (Fig. 6c). The transect averages, and $95 \%$ con- fidence intervals, for the $\mathrm{Chlbc}_{\mathrm{TP}}, \mathrm{PSC}_{\mathrm{TP}}$ and $\mathrm{PPC}_{\mathrm{TP}}$ indices were $0.100 \pm 0.040,0.264 \pm 0.054$ and $0.189 \pm$ 0.108 , respectively.

These differences in the composition of the total pigment pool were further explored by examining the relationships between photo-pigment indices and TChla. For this purpose, TChla was used as an indicator of biomass and trophic division between oligotrophic and meso- plus eutrophic regions, where oligotrophic regions were designated as water masses with TChla of $<0.4 \mathrm{mg} \mathrm{m}^{-3}$. Although the variables in the plotted relationships (Fig. 7) are not strictly independent, the plots are useful for illustrating trends and no regression statistics have been determined. There was considerable scatter in the plot of TChla $\mathrm{TP}_{\mathrm{TP}}$ as function of TChla for concentrations up to $5 \mathrm{mg} \mathrm{m}^{-3}$, but the variation in the index for oligotrophic regions was similar to that for meso- and eutrophic waters (Fig. 7a). In contrast, Chlbc $_{\mathrm{TP}}$ indices were very low in oligotrophic waters and 2 to 3 times greater in mesoand eutrophic waters (Fig. 7b). Similarly, the PSC index tended to be higher in meso- and eutrophic waters compared to oligotrophic regions (Fig. $7 \mathrm{c}$ ). $\mathrm{PPC}_{\mathrm{TP}}$ indices, on the other hand, were very low in
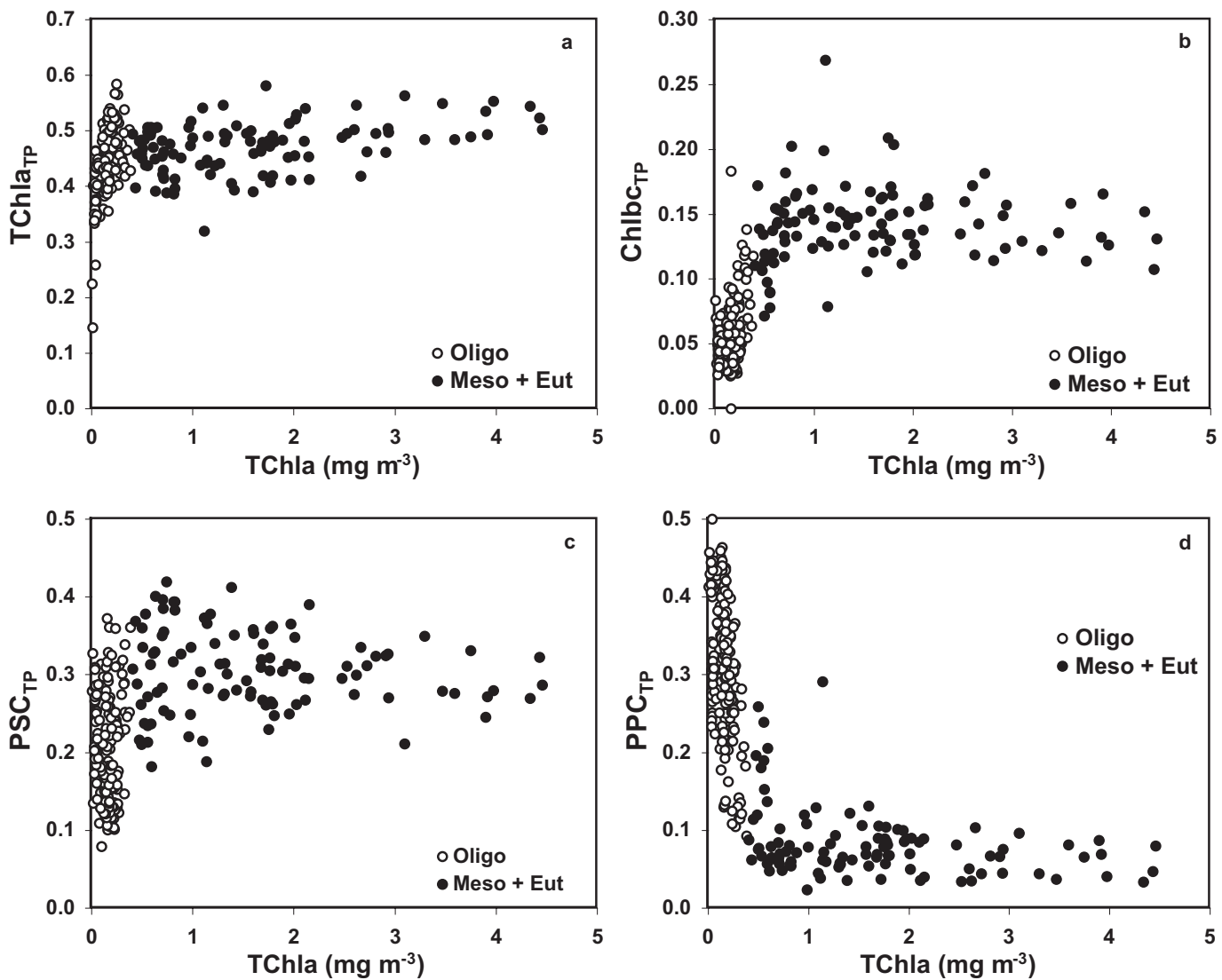

Fig. 7. Regression plots of (a) TChla $\mathrm{TP}_{\text {, }}$ (b) $\mathrm{Chlbc}_{\mathrm{TP}}$ (c) $\mathrm{PSC}_{\mathrm{TP}}$, and (d) $\mathrm{PPC}_{\mathrm{TP}}$, versus TChla concentration. Oligo and Meso + Eut indicate oligotrophic, and mesotrophic plus eutrophic water masses, respectively. See Table 1 for abbreviations 
meso- and eutrophic waters and high in oligotrophic regions (Fig. 7d). The significance of these differences is discussed below.

\section{DISCUSSION}

\section{Community structure}

The data presented here highlight the variation in surface phytoplankton biomass and pigment composition in 5 major regions across $84^{\circ}$ of latitude along the eastern boundary of the Atlantic Ocean. Phytoplankton biomass on the cruise track was much greater in the Benguela ecosystem than in the Canary system (Fig. 6a), and this may be attributed to the positioning of the track (Fig. 1). An inshore track, 30 to $100 \mathrm{~km}$ from the coast, was purposely chosen for the Benguela region so as to conduct measurements in high biomass waters (up to $30 \mathrm{mg} \mathrm{m}^{-3}$, Fig. 4a). Due to logistical constraints, however, the vessel had to sail offshore in the vicinity of $20^{\circ} \mathrm{W}$ longitude through the Canary region (300 to $400 \mathrm{~km}$ offshore, Fig. 1), where there was lower phytoplankton biomass. TChla concentrations of up to $4 \mathrm{mg} \mathrm{m}^{-3}$ (Fig. 4a) were similar to those observed by Babin et al. (1996) at $20.5^{\circ} \mathrm{N}, 18.6^{\circ} \mathrm{W}$. If measurements had been conducted closer inshore to the west African coast, it is likely that high biomass waters, comparable to the Benguela, would have been encountered, as Morel (1982) and Howe (1982) have reported TChla values up to $18 \mathrm{mg} \mathrm{m}^{-3}$ off Mauritania.

There were notable differences in phytoplankton community structure between the Benguela and Canary upwelling ecosystems. The Benguela was dominated by microphytoplankton (60\%), and nanoand picophytoplankton were of secondary and minor importance (Fig. 6b). In contrast, the Canary community consisted of $42 \%$ microplankton and $37 \%$ nanoplankton, with a significant $21 \%$ contribution by picoplankton. These differences may possibly be due to the nutrient status of the water masses. Barlow et al. (2002) reported nitrate levels of 10 to $20 \mu \mathrm{M}$ in the upper $20 \mathrm{~m}$ in the Benguela during AMT-6 and this, together with the high TChla concentrations, indicated eutrophic conditions leading to the dominance by microplankton. Nitrate levels were considerably lower at $1.5 \mu \mathrm{M}$ in the upper $20 \mathrm{~m}$ in the Canary region (Barlow et al. 2002), indicating that the water masses were tending towards mesotrophic conditions at the edge of the upwelling zone, conducive to a more diverse phytoplankton community. Similar observations of low nitrate levels and mixed micro-, nano- and picophytoplankton populations were made by Babin et al. (1996) and Lazzara et al. (1996) at a mesotrophic site in the Canary ecosystem.
Surface biomass levels in the southern oligotrophic region $\left(15.5^{\circ} \mathrm{S}\right.$ to $\left.15^{\circ} \mathrm{N}\right)$ were greater than in the $\mathrm{NE}$ Atlantic gyre (21 to $40^{\circ} \mathrm{N}$, Fig. 6a), and there were also some differences in community composition. Picoplankton were the dominant group in the southern oligotrophic region (59\%), whereas a lower picoplankton proportion $(51 \%)$, together with nanoplankton $(41 \%)$, accounted for most of the biomass in the northern oligotrophic region (Fig. 6b). Varying environmental conditions may possibly account for these differences. Barlow et al. (2002) have shown that the euphotic zone, nitraclines and subsurface chlorophyll maxima tend to be shallower in the southern region $(\sim 40 \mathrm{~m})$ than the northern region $(\sim 150 \mathrm{~m})$. DVChla and zeaxanthin concentrations were about $0.1 \mathrm{mg} \mathrm{m}^{-3}$ in the shallow euphotic zones in the south, compared to levels of 0 to $0.05 \mathrm{mg} \mathrm{m}^{-3}$ in the deep euphotic zones in the north. It appears that the prokaryote cells exploit a more readily available supply of micronutrients in the shallower nitracline waters in the southern region, leading to an elevation in phytoplankton biomass relative to the north.

These observations for the eastern Atlantic are consistent with other investigations in various sectors of the world ocean. Latasa \& Bidigare (1998) and Barlow et al. (1999) reported the presence of diatomnanoflagellate communities in upwelled waters in the Arabian Sea in response to monsoonal activity, and the dominance of the picophytoplankton in oligotrophic, low chlorophyll waters towards the equator. A transect study across the north Pacific by Ondrusek et al. (1991) revealed the dominance of diatoms (fucoxanthin) in nitrate-rich coastal waters, with cyanobacterial dominance (zeaxanthin) in nitrate-poor mid-ocean regions. The importance of the cyanobacteria and nanoflagellates in tropical and sub-tropical waters has been confirmed in a number of other investigations, as noted by Letelier et al. (1993), Claustre \& Marty (1995), Bidigare \& Ondrusek (1996), Mackey et al. (1998) and Goericke et al. (2000).

DVChla is an exclusive biomarker of prochlorophytes (Goericke \& Repeta 1993), and the significance of DVChla in the Atlantic Ocean has been discussed extensively by Gibb et al. (2000, 2001). In this study, the contribution of prochlorophytes to TChla was generally $<20 \%$ in the Canary region, while the average contribution was $30 \%$ at 20 to $30^{\circ} \mathrm{N}$, and $20 \%$ between 30 and $43^{\circ} \mathrm{N}$ (Fig. $4 \mathrm{~b}$ ). The proportion in the southern oligotrophic region was much greater, however, averaging about $50 \%$, but proportions $>60 \%$ and up to $68 \%$ were observed between $11^{\circ} \mathrm{S}$ and $9^{\circ} \mathrm{N}$ (Fig. $4 \mathrm{~b}$ ). Thus, prochlorophytes appear to be the most important component of the phytoplankton community in surface waters of the southern oligotrophic region in May and June 1998. Gibb et al. (2000) reported similar high pro- 
portions of prochlorophytes off Brazil, and collectively, these studies suggest that there is a consistency of high prochlorophyte biomass in surface oligotrophic waters along both the eastern and western boundaries of the South Atlantic.

\section{Pigment adaptation}

As discussed above, phytoplankton displays the unique ability of changing the structure of the community to adapt to changing environmental conditions (Gibb et al. 2000, Trees et al. 2000), and this influences the variation in pigment composition across the 5 regions. Chlorophyll $a$ is the major pigment in phytoplankton, but the inter-regional differences in the TChla proportion was small, ranging from 40 to

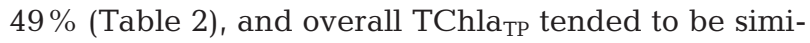
lar in oligo-, meso- and eutrophic waters (Fig. 7a), averaging $45 \%$. The chlorophyll a proportion of the total pigments in surface phytoplankton appears to be highly conserved, as implied by Trees et al. (2000) through accessory pigment versus chlorophyll a relationships, and this means that the accessory pigments play an important role in adaptive strategies. The substantial elevation in the $\mathrm{Chlbc}_{\mathrm{TP}}$ index in meso- and eutrophic waters (Fig. 7b), indicated that the accessory chlorophylls $b$ and $c$ were greater in the Benguela, Canary and temperate NE Atlantic regions, thereby increasing the total chlorophyll proportion to $57-63 \%$ in these ecosystems (Table 2). Chlorophylls $a, b$ and $c$ appear, therefore, to perform the major light-harvesting role in high productivity regions, and the Benguela region was particularly noteworthy as the total chlorophyll pool was significantly higher at $63 \%$ than in the other regions (Table 2). The total chlorophyll pool in the oligotrophic regions was lower at 45 to $51 \%$, as a consequence of a very low contribution by the accessory chlorophylls (Table 2). This chlorophyll proportion was twice that of the photosynthetic carotenoids, however, indicating that the chlorophylls were also the key light-harvesting pigments in low productivity waters.

Table 2. Mean proportional contribution (\%) of each photo-pigment group to the total pigment pool in each region. PSC: photosynthetic carotenoids; PPC: photoprotective carotenoids

\begin{tabular}{|lcrcrrc|}
\hline Region & $\begin{array}{c}\text { Total } \\
\text { Chl } a\end{array}$ & $\begin{array}{c}\text { Chl } \\
b \text { and } c\end{array}$ & $\begin{array}{c}\text { Total } \\
\text { chlorophylls }\end{array}$ & PSC & PPC & $\begin{array}{c}\text { Total } \\
\text { carotenoids }\end{array}$ \\
\hline $50-40^{\circ} \mathrm{N}$ & 44.7 & 12.8 & 57.5 & 32.1 & 10.4 & 42.5 \\
$40-21^{\circ} \mathrm{N}$ & 40.4 & 4.7 & 45.1 & 22.4 & 32.5 & 54.9 \\
$21-15^{\circ} \mathrm{N}$ & 44.5 & 12.7 & 57.2 & 29.9 & 12.9 & 42.8 \\
$15^{\circ} \mathrm{N}-15.5^{\circ} \mathrm{S}$ & 46.0 & 5.2 & 51.2 & 17.3 & 31.5 & 48.8 \\
$15.5-34^{\circ} \mathrm{S}$ & 48.9 & 14.4 & 63.3 & 30.0 & 6.7 & 36.7 \\
\hline
\end{tabular}

The PSC $_{\mathrm{TP}}$ index was elevated in meso- and eutrophic waters (Fig. 7c), yielding photosynthetic carotenoid proportions of $30-32 \%$ in the high productivity regions, relative to $17-22 \%$ for oligotrophic waters (Table 2 ). In contrast, the $\mathrm{PPC}_{\mathrm{TP}}$ index was very low in meso- and eutrophic waters and substantially greater in oligotrophic waters (Fig. 7d), resulting in photoprotective carotenoid proportions of $7-13 \%$ in the productive regions, but $32 \%$ in oligotrophic regions (Table 2). The total carotenoid pool was, therefore, significantly greater at $49-55 \%$ in the oligotrophic regions, as opposed to $37-43 \%$ in the Benguela, Canary and temperate NE Atlantic regions. These observations reveal that carotenoids tend to have a more important role in oligotrophic waters, mainly in a photoprotective capacity. This is well documented in other studies by Babin et al. (1996), Lazzara et al. (1996) and Gibb et al. (2000) for the tropical Atlantic, by Allali et al. (1997) for the subequatorial Pacific, and by Stuart et al. (1998) and Sathyendranath et al. (1999) for the Arabian Sea.

Accessory pigment change in relation to phytoplankton structure is explored further in the relationships in Fig. 8. Although the variables are not strictly independent, the plots are useful for indicating trends. The total chlorophyll $c$ ( TChl $_{\mathrm{TP}}$ ) and $\mathrm{PSC}_{\mathrm{TP}}$ indices increased concomitantly with an increase in the Micro $_{\text {DP }}$ index (Fig. 8a,b), indicating that diatoms and dinoflagellates increased the proportion of chlorophyll $C$ and photosynthetic carotenoids to optimise their light-harvesting capability. This was corroborated by Stuart et al. (1998) and Barlow et al. (2002) who showed that absorption at $440 \mathrm{~nm}$ in diatomdominated communities is due to chlorophylls $a$ and $C_{\text {, }}$ and at $490 \mathrm{~nm}$ to photosynthetic carotenoids. The increase in $\mathrm{PSC}_{\mathrm{TP}}$ with $\mathrm{Nano}_{\mathrm{DP}}$ (Fig. 8c) suggests that photosynthetic carotenoids play an important lightharvesting role in nanoflagellate populations, while the concomitant increase in $\mathrm{PPC}_{\mathrm{TP}}$ with $\mathrm{PiCO}_{\mathrm{DP}}$ (Fig. 8d) confirms the high photoprotective carotenoid content in picoplankton. This high PPC content reduced the photosynthetic chlorophyll and carotenoid pool to a mean of $68 \%$ in picoplankton-dominated communities (40 to $21^{\circ} \mathrm{N}, 15^{\circ} \mathrm{N}$ to $15.5^{\circ} \mathrm{S}$ ). Where microplankton and/or nanoplankton dominated, the photosynthetic pigment pool was $93 \%, 87 \%$ and $90 \%$ in the Benguela, Canary and temperate NE Atlantic regions, respectively. This high photosynthetic pigment content may partially explain the elevated productivity in these regions compared to the low productivity in oligotrophic waters. The suggestion by Sosik \& Mitchell (1995) and Babin et al. (1996) 

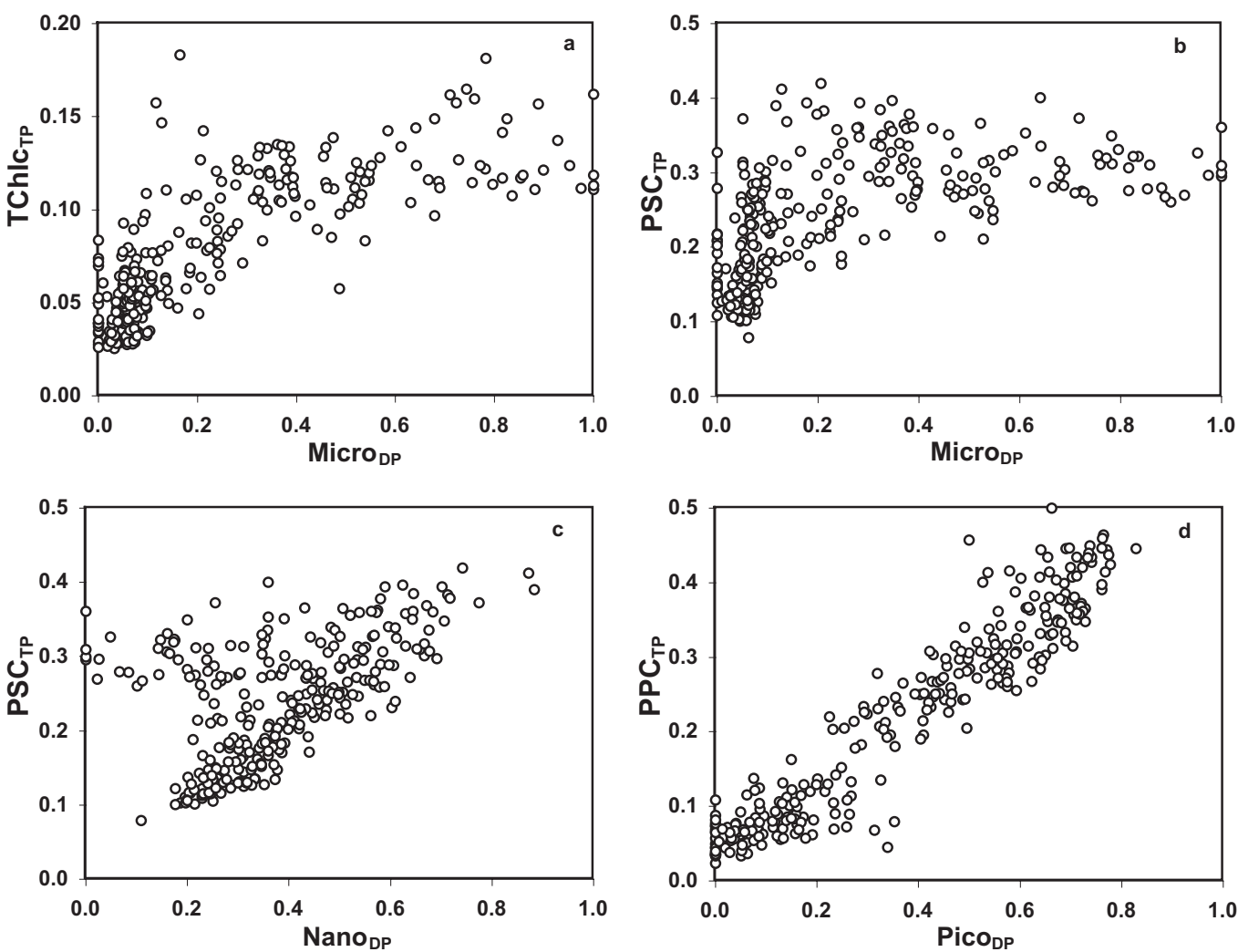

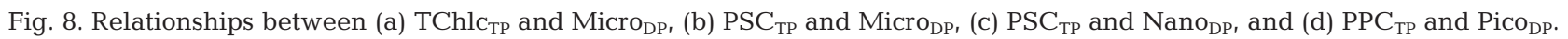
See Table 1 for abbreviations

that only photosynthetically active components be used in bio-optical models of primary production appears to be a sound one.

These surface pigment adaptations are likely to be related to, or controlled by, the nutrient regime in the different regions. During AMT-6, the Benguela region was characterised by elevated nitrates (10 to $20 \mu \mathrm{M}$, Barlow et al. 2002) and biomass, diatom domination, a high proportion of chlorophylls and a low $\mathrm{PPC}_{\mathrm{TP}}$ index. Diatoms are opportunistic organisms that are able to respond rapidly to nitrate enrichment (Fogg 1991), and chlorophyll molecules contain nitrogen atoms, while carotenoids do not (Porra et al. 1997). This 'nitrogen' characteristic of diatoms and chlorophylls probably explains the dominance of diatoms and the elevated chlorophyll pool in the Benguela ecosystem. The Canary and temperate NE Atlantic regions had lower nitrate concentrations $(0.5$ to $1.5 \mu \mathrm{M}$, Barlow et al. 2002) and biomass, a greater contribution of nanoplankton in the community, a $6 \%$ lower chlorophyll pool compared to the Benguela, and an increased $\mathrm{PPC}_{\mathrm{TP}}$ index. In the oligotrophic regions, nitrates were below detection limits (Barlow et al. 2002), biomass was very low, the communities were dominated by picoplankton, chlorophyll pools were 12 to $18 \%$ lower than the Benguela, and the $\mathrm{PPC}_{\mathrm{TP}}$ indices were the highest (Table 2). Thus, there appears to be a synchronicity between the decrease in nitrate concentrations, the change in community structure, and the decline in the proportion of the chlorophyll pool. Concomitantly, there was an inverse relationship between the decrease in nitrates and the increase in the $\mathrm{PPC}_{\mathrm{TP}}$ index. Similar relationships for nitrate and photoprotective carotenoids have been observed by Babin et al. (1996), Johnson et al. (2002) and Lazzara et al. (1996) in the tropical NE Atlantic and Arabian Sea. It appears that nitrogen has a significant role in regulating the pattern of change within the pigment pool in surface phytoplankton, and these changes are related to shifts in community structure rather than acclimation by the same population. These observations also suggest that photoadaptation is greater in the Benguela, Canary and NE Atlantic regions where the photosynthetic chlorophylls and carotenoids accounted for 87 to $93 \%$ of total pigments, as opposed to $68 \%$ in the oligotrophic regions. The phytoplankton in the high productivity regions are therefore likely to have greater absorption and photosynthetic efficiencies, leading to elevated primary production and biomass, since phytoplankton in oligotrophic waters usually have reduced 
photosynthetic efficiency when photoprotective pigments are high (Babin et al. 1996, Johnson et al. 2002).

This study has demonstrated the significant regional differences in surface phytoplankton and pigment characteristics along the eastern boundary of the Atlantic Ocean. The Benguela had a 3-fold greater phytoplankton biomass than the Canary and temperate NE Atlantic regions, comprising a microplankton community with a high content of photosynthetic chlorophylls and carotenoids. Although the biomass levels were considerably lower in the oligotrophic regions, the chlorophyll a concentration in the southern oligotrophic region was twice that in the northern oligotrophic region. Both oligotrophic regions were dominated by picoplankton, containing a high proportion of photoprotective carotenoids and a reduced pool of photosynthetic pigments. These differing proportions of photosynthetic and photoprotective pigments in phytoplankton across $84^{\circ}$ of latitude may be useful in the development of bio-optical models for estimating primary production over basin scales in the Atlantic Ocean.

Acknowledgements. We sincerely thank the officers and crew of the RRS 'James Clark Ross' for their skilled co-operation and assistance during the cruise; M. Ondrusek and R. Bidigare (University of Hawaii) for supplies of divinyl chlorophylls $a$ and $b$; the SeaWiFS Project, NASA Goddard Space Flight Centre for satellite data. RGB thanks the GTZ BENEFIT programme for financial support associated with the cruise. This is AMT contribution number 47.

\section{LITERATURE CITED}

Aiken J, Moore GF, Holligan PM (1992) Remote sensing of oceanic biology in relation to global climate change. J Phycol 28:579-590

Aiken J, Rees N, Hooker S, Holligan P and 5 others (2000) The Atlantic Meridional Transect: overview and synthesis of data. Prog Oceanogr 45:257-312

Allali K, Bricaud A, Claustre H (1997) Spatial variations in the chlorophyll-specific absorption coefficients of phytoplankton and photosynthetically active pigments in the equatorial Pacific. J. Geophys Res 102:12413-12423

Babin M, Morel A, Claustre H, Bricaud A, Kolber Z, Falkowski PG (1996) Nitrogen- and irradiance-dependent variations of the maximum quantum yield of carbon fixation in eutrophic, mesotrophic and oligotrophic marine systems. Deep-Sea Res Part I 43:1241-1272

Barlow RG, Cummings DG, Gibb SW (1997) Improved resolution of mono- and divinyl chlorophylls $a$ and $b$ and zeaxanthin and lutein in phytoplankton extracts using reverse phase C-8 HPLC. Mar Ecol Prog Ser 161:303-307

Barlow RG, Mantoura RFC, Cummings DG (1999) Monsoonal influence on the distribution of phytoplankton pigments in the Arabian Sea. Deep-Sea Res Part II 46:677-699

Barlow RG, Aiken J, Holligan PM, Cummings DG, Maritorena S, Hooker S (2002) Phytoplankton pigment and absorption characteristics along meriodinal transects in the Atlantic Ocean. Deep-Sea Res Part I 49:637-660
Bidigare RR, Ondrusek ME (1996) Spatial and temporal variability of phytoplankton pigment distributions in the central equatorial Pacific Ocean. Deep-Sea Res Part II 43: 809-833

Claustre H, Marty JC (1995) Specific phytoplankton biomasses and their relation to primary production in the tropical North Atlantic. Deep-Sea Res Part I 42:1475-1493

Fogg GE (1991) The phytoplanktonic ways of life. New Phytol 118:191-232

Gibb SW, Barlow RG, Cummings DG, Rees NW, Trees CC, Holligan P, Suggett D (2000) Surface phytoplankton pigment distributions in the Atlantic Ocean: an assessment of basin scale variability between $50^{\circ} \mathrm{N}$ and $50^{\circ} \mathrm{S}$. Prog Oceanogr 45:339-368

Gibb SW, Cummings DG, Irigoien X, Barlow RG, Mantoura RFC (2001) Phytoplankton pigment chemotaxonomy of the northeastern Atlantic. Deep-Sea Res Part II 48: 795-823

Goericke R, Repeta DJ (1993) Chlorophylls $a$ and $b$ and divinyl chlorophylls $a$ and $b$ in the open subtropical North Atlantic Ocean. Mar Ecol Prog Ser 101:307-313

Goericke R, Olson RJ, Shalapyonok A (2000) A novel niche for Prochlorococcus sp. in low-light suboxic environments in the Arabian Sea and the Eastern Tropical North Pacific. Deep-Sea Res Part I 47:1183-1205

Howe S (1982) A simulation study of biological responses to environmental changes associated with coastal upwelling off Northwest Africa. Rapp p-V Réun Cons Int Explor Mer 180:135-147

Jeffrey SW (1976) A report on green algal pigments in the central North Pacific Ocean. Mar Biol 37:33-37

Jeffrey SW, Vesk M (1997) Introduction to marine phytoplankton and their pigment signatures. In: Jeffrey SW, Mantoura RFC, Wright, SW (eds) Phytoplankton pigments in oceanography. UNESCO, Paris, p 37-84

Johnson Z, Bidigare RR, Goericke R, Marra J, Trees C, Barber RT (2002) Photosynthetic physiology and physiochemical forcing in the Arabian Sea, 1995. Deep-Sea Res Part I 49: $415-436$

Kana TM, Glibert PM, Goericke R, Welschmeyer NA (1988) Zeaxanthin and $\beta$-carotene in Synechococcus WH7803 respond differently to irradiance. Limnol Oceanogr 33: $1623-1627$

Kirk JTO (1994) Light and photosynthesis in aquatic ecosystems, 2nd edn. Cambridge University Press, Cambridge

Latasa M, Bidigare RR (1998) A comparison of phytoplankton populations of the Arabian Sea during the spring intermonsoon and southwest monsoon of 1995 as described by HPLC pigments. Deep-Sea Res Part II 45:2133-2170

Lazzara L, Bricaud A, Claustre H (1996) Spectral absorption and fluorescence excitation properties of phytoplanktonic populations at a mesotrophic and an oligotrophic site in the tropical North Atlantic (EUMELI program). Deep-Sea Res Part I 43:1215-1240

Letelier RM, Bidigare RR, Hebel DV, Ondrusek M, Winn CD, Karl DM (1993) Temporal variability of phytoplankton community structure based on pigment analysis. Limnol Oceanogr 38:1420-1437

Longhurst A, Sathyendranath S, Platt T, Caverhill C (1995) An estimate of global primary production in the ocean from satellite radiometer data. J Plankton Res 17:1245-1271

Mackey DJ, Higgins HW, Mackey MD, Holdsworth D (1998) Algal class abundances in the western equatorial Pacific: estimation from HPLC measurements of chloroplast pigments using CHEMTAX. Deep-Sea Res Part I 45: 1441-1468

Maranon E, Holligan PM (1999) Photosynthetic parameters of 
phytoplankton from $50^{\circ} \mathrm{N}$ to $50^{\circ} \mathrm{S}$ in the Atlantic Ocean. Mar Ecol Prog Ser 176:191-203

Maranon E, Holligan PM, Varela M, Mourino B, Bale AJ (2000) Basin-scale variability of phytoplankton biomass, production and growth in the Atlantic Ocean. Deep-Sea Res Part I 47:825-857

Moore LR, Goericke R, Chisholm SW (1995) Comparative physiology of Synechococcus and Prochlorococcus: influence of light and temperature on growth, pigments, fluorescence and absorptive properties. Mar Ecol Prog Ser 116:259-275

Morel A (1982) Optical properties and radiant energy in the waters of the Guinea Dome and the Mauritanian upwelling area in relation to primary production. Rapp p-V Réun Cons Int Explor Mer 180:94-107

Ondrusek ME, Bidigare RR, Sweet ST, Defreitas DA, Brooks JM (1991) Distribution of phytoplankton pigments in the North Pacific Ocean in relation to physical and optical variability. Deep-Sea Res Part I 38:243-266

O'Reilly JE, Maritorena S, Mitchell BG, Siegel DA, Carder KL, Garver SA, Kahru M, McClain C (1998) Ocean colour chlorophyll algorithms for SeaWiFS. J Geophys Res 103: 24937-24953

Porra RJ, Pfündel EE, Engel N (1997) Metabolism and function of photosynthetic pigments. In: Jeffrey SW, Mantoura

Editorial responsibility: Otto Kinne (Editor), Oldendorf/Luhe, Germany
RFC, Wright, SW (eds) Phytoplankton pigments in oceanography. UNESCO, Paris, p 85-126

Sathyendranath S, Stuart V, Irwin BD, Maass H, Savidge G, Gilpin L, Platt T (1999) Seasonal variations in bio-optical properties of phytoplankton in the Arabian Sea. Deep-Sea Res Part II 46:633-653

Simon N, Barlow RG, Marie D, Partensky F, Vaulot D (1994) Characterization of oceanic photosynthetic picoeukaryotes by flow cytometry. J Phycol 30:922-935

Sosik HM, Mitchell BG (1995) Light absorption by phytoplankton, photosynthetic pigments and detritus in the California Current System. Deep-Sea Res Part I 42:1717-1748

Stuart V, Sathyendranath S, Platt T, Maass H, Irwin BD (1998) Pigments and species composition of natural phytoplankton populations: effect on the absorption spectra. J Plankton Res 20:187-217

Trees CC, Clark DK, Bidigare RR, Ondrusek ME, Mueller JL (2000) Accessory pigments versus chlorophyll a concentrations within the euphotic zone: a ubiquitous relationship. Limnol Oceanogr 45:1130-1143

Vidussi, F, Claustre H, Manca BB, Luchetta A, Marty JC (2001) Phytoplankton pigment distribution in relation to upper thermocline circulation in the eastern Mediterranean Sea during winter. J Geophys Res 106: 19939-19956

Submitted: September 2, 2003; Accepted: June 17, 2004 Proofs received from author(s): October 6, 2004 